\title{
Environmental Standards and Trade Volume
}

\author{
Nicholas Mangee*, Bruce EImslie \\ University of New Hampshire, Department of Economics, Whittemore School of Business and Economics, Durham USA \\ E-mail:njf7@unh.edu,bte@cisunix.unh.edu \\ Received June 10, 2010; revised July 20, 2010; accepted July 24, 2010
}

\begin{abstract}
This paper presents a theoretical and empirical analysis of the effects of environmental regulation on bilateral trade volume. We use a gravity model of trade flows and find weak evidence that differences in regulation are a source of comparative advantage. We also find evidence against the race-to-the-bottom hypothesis in that increases in standards in both high and low standard countries increase bilateral trade volume. We use 1999 data on GDP, population, and environmental stringency for 39 countries.
\end{abstract}

Keywords: Environmental Standards, Trade Volume, Gravity Model, Comparative Advantage

\section{Introduction}

The link between environmental regulation and international trade has warranted considerable attention by economists, environmentalists and policy makers alike. A substantial amount of theoretical and empirical research has addressed the question of how environmental stringency affects international trade. Conventional trade theory suggests that country characteristics, such as land and capital define comparative advantage. Environmental quality, endowments, capacities and policies have also been considered as determinants of each country's comparative advantage ${ }^{1}$.

This paper develops a model of comparative advantage based on differences in environmental regulation between countries. We then use a gravity model to test the hypothesis that as the differences in environmental regulation across countries increase, bilateral trade flows also increase as predicted by the theory. Differences in regulation are found to have a positive but weak effect on bilateral trade volume.

This result could also be consistent with a race-to-thebottom in terms of environmental standards for low standard countries. Therefore, we develop a second test between overall standards and trade volume. We find strong evidence that increased standards by both countries promotes bilateral trade volume. Thus, even if trade volume is positively associated with differences in regulation, no

\footnotetext{
"We want to thank Robert Mohr, Michael Goldberg, Edinaldo Tebaldi, Torsten Schmidt and Sinthy Kounlasa for useful discussion and assistance.

${ }^{1}$ For analysis on the environment and comparative advantage see Pethig
} [1] and Siebert [2]. incentive appears to exist for low standard countries to increase trade flows by lowering standards.

The existing literature has yet to demonstrate the effect of differentiated regulation on gross bilateral trade flows across a large set of countries. Previous studies have examined the effect that regulation has on the composition of trade regarding one country or a small set of countries. Other studies have demonstrated regulation in isolation, failing to examine the collective differences between stringency as a source of comparative advantage. Given the ubiquitous nature of comparative advantage in the theoretical determination of trade patterns between countries, it is surprising that many of the existing studies have eschewed this approach. This paper represents the first study of the effects of environmental regulation on trade volume that fully incorporates comparative advantages created by differentiated environmental regulation between trading partners.

Within the last three decades, two popular positions have emerged regarding the interaction of stringency and international trade in environmentally intensive goods rather than in overall trade volume. The first hypothesis suggests that, as a country imposes higher environmental regulations, the cost of production increases. This may result in a decrease in exports of pollution intensive goods and an increase in imports. Thus, higher stringency may lead to a decrease in comparative advantage in pollution intensive goods for a country $[3,4]$. Furthermore, to maintain international competitiveness, a country may purposefully set lax environmental standards. This potential global degradation in stringency is consistent with the race-to-the-bottom hypothesis. These theories hypothesize that in order to not lose the business 
of pollution intensive goods whose production may be shipped abroad, countries deliberately race-to-the-bottom in environmental regulations. Similarly, these costs incurred by increasing a firm's total cost of production coupled with the "pollution haven hypothesis" suggest that pollution intensive production will migrate to regions of lax regulations [5,6]. With low environmental demand, developing countries may attempt to increase their share of the global market by setting lax regulations creating a comparative advantage in pollution intensive goods [7]. The empirical performance of these hypotheses has been poor $[3,8,9]$. Our results represent the first clear empirical case that comparative advantage is not associated with the development of pollution havens, because higher standards of low standard countries increases rather than decreases bilateral trade volume.

The contrasting hypothesis concerning the effect of environmental stringency on foreign trade is the Porter hypothesis $[10,11]$. This hypothesis predicts that an increase in environmental regulation will stimulate advancements in environmentally friendly technology. This tightening of standards will encourage firms to seek new technology for the long run and possibly differentiate their products by producing environmentally friendly ones. Porter, however, makes no distinction between high and low standard countries in terms of the relationship between inventiveness and trade volume. However, a loose interpretation of Porter is that countries should not fear that increased regulation will necessarily decrease trade volume. It may even increase trade volume as increased standards increase the incentive to innovate. The test that we develop supports this loose interpretation of Porter.

\section{Empirical Framework and Literature Review}

There is a vast literature on the relationship between standards and international trade. ${ }^{2}$ Typically, the methodological approach for determining the effect of regulation on trade involves a supply side model incorporating the determinants of international trade. The conventional supply side approach has followed a Heckscher-Ohlin-Samuelson (HOS) theoretical framework and often the Heckscher-Ohlin-Vanek (HOV) model in empirical work.

The HOS model predicts that a country will export the good that intensively uses its relatively abundant factor. The environment is incorporated in HOS as a factor of production predicting that a country with a greater environmental capacity for pollutants is relatively better endowed and will export pollution intensive goods. The HOV model allows for a direct empirical test by predict-

${ }^{2}$ For an overview of the literature and methodologies see Alpay [12] and Van Beers and Van Den Bergh [13]. ing the factor composition of trade for a country based on factor abundance. This model has been widely applied within the environmental trade literature as it allows for trade to be decomposed by pollution intensity and industry.

Tobey [9] uses a cross section HOV model to investigate whether increased domestic regulation during the 1960's and 1970's affected trade patterns in pollution intensive industries. Using 23 countries and 1975 data, he regresses trade in pollution intensive commodities across countries on resource endowment characteristics such as land area, literate workers, and capital. The results suggest that there is no significant effect of increased environmental stringency on net exports of pollution intensive goods. Tobey [9] does not investigate the role of regulatory differences specifically in explaining trade flows between countries.

Ratnayake [3] takes an inter industry trade approach consisting of 109 industries over a 13 year period (19801993) in New Zealand. Following the HOS/HOV models, New Zealand, as a developed capital abundant country is expected to possess a comparative advantage in the production of goods that intensively use capital in production. Ratnayake uses a revealed comparative advantage (RCA) index to determine if increased environmental standards lead to a decrease in competitiveness in the manufacturing sector. By comparing trade behavior of New Zealand's to four other country groups (world, OECD, ASEAN, and DC's) this study finds that, in spite of high environmental stringency in New Zealand, it's exports in pollution intensive, or environmentally sensitive goods was not decreased.

Unlike Ratnayake, a number of other studies have shown an increase in environmental standards to have a negative impact on the exports of pollution intensive industries. Wilson and colleagues [14] takes a developing country perspective of stringency on trade by examining the export behavior of 24 countries (6 OECD and 18 non-OECD) between 1994 and 1998 for 5 pollution intensive industries. Utilizing the HOV model, this study finds that more stringent environmental standards result in lower exports of pollution intensive goods. Moreover, this study suggests that increased environmental standards have a significantly greater impact on exports of developing countries than developed ones.

It is well known that the HOV equation is inconsistent with trade data [15]. Given these weak general foundations, it is not surprising that the results of HOV models applied to the relationship between environmental standards and trade volume have been inconsistent at best. Alternative approaches, therefore, need to be considered.

Given the empirical problems with the HOV model, we utilize a gravity framework that incorporates differentiated environmental regulation as a source of bilateral trade volume. Such a model of international trade was first developed by Tinbergen [16] to model trade volume 
between two countries in terms of their GDP's and the geographical distance between them. ${ }^{3}$ The gravity model, after being log linearized, takes the following form:

$$
\ln X_{i j}=\beta_{0}+\beta_{1} \ln G D P_{i}+\beta_{2} \ln G D P_{j}+\beta_{3} D I S T_{i j}+v_{i j}
$$

Where:

In denotes the natural logarithm;

$X_{i j}$ denotes gross bilateral trade flows between country $i$ and $j$;

$G D P_{i}, G D P_{j}$ denote the GDP of country $i$ and $j$ respectively;

$D I S T_{i j}$ denotes the distance between country $i$ and $j$;

$v_{i j}$ denotes the error term.

$\beta_{0}, \beta_{1}, \beta_{2}, \beta_{3}$ are parameters.

The expected relationship between these variables is as follows: since the dependent variable is gross bilateral trade volume, the signs of $\beta_{1}$ and $\beta_{2}$ are expected to be positive since larger countries trade more with each other. The parameter $\beta_{3}$ is expected to be negative due to transportation costs. However, the variable $D I S T_{i j}$ may represent any factor that impedes trade. Such factors that have been considered include language, historical, and cultural differences. These characteristics are expected to have a negative relationship with the volume of trade between two countries. In addition, a dummy variable controlling for a border effect is often included in empirical work and is normally found to be significant and positive for countries sharing a border. The gravity model is used in the present study because it incorporates gross bilateral trade volume between countries as the dependant variable and it allows for a large number of countries to be analyzed. Furthermore, in contrast to the HOS/HOV performance, the gravity model performs much better empirically. The gravity model has not yet been utilized as a theoretical tool revealing comparative advantage arising from differences in environmental regulation.

The empirical literature incorporating regulation into the gravity model include Jug and Mirza [18]; Grether and Melo [5]; Van Beers and Van Den Bergh [19]; and Harris and colleagues [20]. Some studies applying the gravity model decompose total trade into imports and exports and further into (non) pollution intensive imports and/or exports, in an attempt to capture the effect of increased stringency on total trade volume. Jug and Mirza $[18]^{4}$ show that increases in environmental expenditures result in a decrease in net exports. These results are consistent with the pollution havens hypothesis and run

\footnotetext{
${ }^{3}$ For an overview of the gravity model see Head [17].

${ }^{4}$ For previous studies applying the gravity model to trade and the environment see Jug and Mirza [18] and references therein.
}

counter to our so-called "loose" interpretation of the Porter hypothesis.

In testing the effects of increased stringency on bilateral exports, Van Beers and Van Den Bergh [19] find a strong negative relationship between total exports and total imports of 21 OECD countries. Part of this study gives evidence to support the pollution havens hypothesis while the negative effect of standards on a developed country's imports presents a surprising result. This result may suggest the presence of import barriers when regulation is increased within a country. Another study that decomposes bilateral trade volume into imports and exports is Grether and Melo [5]. They test total imports against pollution intensive imports as well as non-resource based (footloose) imports against resource based (non-footloose) imports. This study finds support for the pollution haven hypothesis for the footloose industries due to the increase in imports for developed countries when firms are allowed to migrate across countries.

The gravity studies have shown no robust conclusive evidence of the effect of regulation on trade flows [18]. The lack of consensus within this literature may stem from the lack of a comprehensive measure of the environment or regulatory stringency. Measures of stringency should incorporate various indicators of a country's standards, enforcement and policy implementation. Most data sets used in previous studies are either not comprehensive or they cover a small sample of countries. The present study utilizes a recent 2001 comprehensive measure of environmental stringency over a large sample of countries. In addition to the data problem, the literature to date has been limited by the Solomon-like choice between theory and empirics. Researchers choosing the general HOS-HOV approach are able to base their study on a solid theoretical foundation, but must pay in terms of weak empirical support. The well-known empirical shortcomings of the HOV model with regard to the factor content of trade in factors such as capital and various qualities of labor also plague environmental endowment measures. On the other hand, researchers choosing the gravity approach are able to tap into a solid empirical framework but must pay in terms of theoretical underpinnings. As a result, this literature has developed on an ad hoc basis.

We argue that such a choice is not necessary. We augment the work of Helpman and Krugman [21] and Helpman [22] on the theoretical foundation of a gravity equation to make theoretical predictions regarding the effect of differential standards on trade volume. In so doing, we are able to develop an empirical gravity model with the strong theoretical underpinnings of an HOS approach.

\section{Theory}

The relationship between environmental standards and 
bilateral trade volume can be developed in a straight forward manner using a $2 \times 2 \times 2$ factor proportions model. However, as a basis for empirical work using a gravity equation, the factor proportions model has little to contribute. In this section we first develop the factor proportions model using the environment as one factor of production. Then we extend the analysis to allow for one sector to produce differentiated products within a monopolistically competitive setting. This approach allows for the gravity model and comparative advantage based on differential environmental standards to jointly determine trade volume.

\subsection{The Factor Proportions Model}

Consider a $2 \times 2 \times 2$ economy producing goods manufacture (M) and food (F) with factors labor (L) and the environment $(\mathrm{E})$. The manufactured good is $\mathrm{E}$ intensive. Consumers in each country maximize identical homothetic utility functions. Foreign variables will be designated by $*$.

Figure 1 shows the relevant factor-price equalization set for such an economy. $\mathrm{O}$ is the Home origin.

The world output of $\mathrm{M}$ and $\mathrm{F}$ are given by $O A(O$ * $\left.A^{\prime}\right)$ and $O A^{\prime}(O * A)$ respectively.

First, allow the relative endowments to be equal be- tween countries so that the endowment point falls on the diagonal such as at point $\mathrm{C}$. Home production and consumption of the manufactured good and food are at $\mathrm{OC}_{\mathrm{M}}$ and $\mathrm{OC}_{\mathrm{F}}$ respectively. Thus with equal relative endowments, autarky prevails.

Next allow the relative endowment to move along line segment B'B from $C$ to $G$. Relative consumption remains at $C$, but production of $M$ increases for Home to $\mathrm{OQ}_{M}$, while foreign production of $M$ decreases from $C_{M} A$ to $\mathrm{Q}_{\mathrm{M}} \mathrm{A}$. Similarly for food, Home production falls to $\mathrm{OQ}_{\mathrm{F}}$ while Foreign production increases to $A^{\prime} Q_{F}$. Home exports $\mathrm{Q}_{\mathrm{M}} \mathrm{C}_{\mathrm{M}}$ and imports $\mathrm{C}_{\mathrm{F}} \mathrm{Q}_{\mathrm{F}}$.

However, the move need not be along a given relative GDP line. Under factor-proportions theory trade volume (VT) is a function of relative endowment differences. Thus country size is not an independent determinant of trade volume. As shown in another form by Helpman and Krugman [21], assuming Home is $E$ abundant:

$$
V T=\lambda_{E} E+\lambda_{L} L
$$

where $\lambda_{E}>0$ and $\lambda_{L}<0$ above the diagonal OO*. Therefore isotrade lines within the factor-price equalization set $O A O^{*} A^{\prime}$ are linear with slopes $\mathrm{OO}^{*}$ and with VT increasing monotonically from zero along $\mathrm{OO}^{*}$ to a maximum when relative endowments are at $A\left(A^{\prime}\right)$. This can be expressed as Proposition 1.

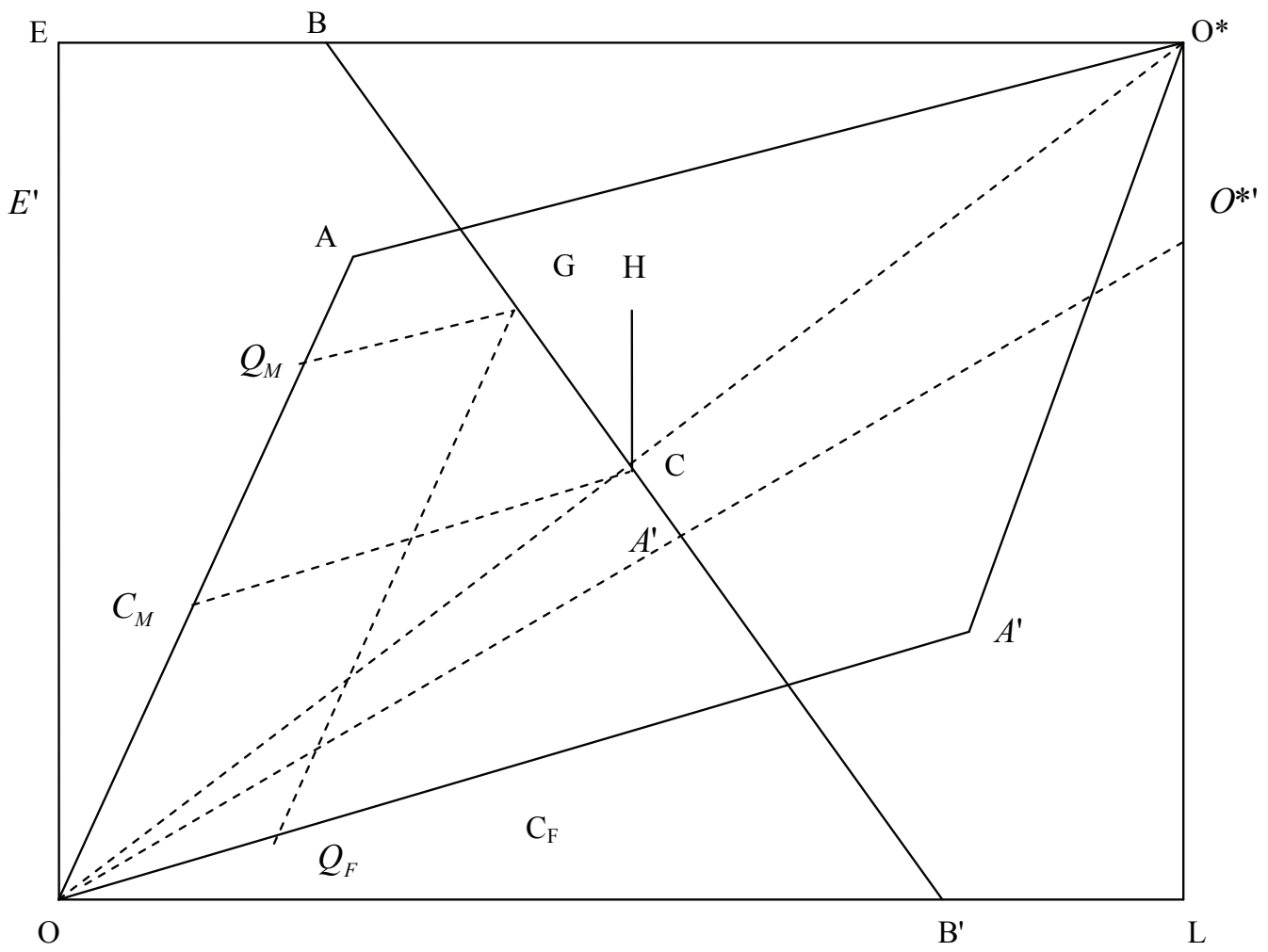

Figure 1. Factor-price equalization set for economy. 


\section{Proposition 1}

Trade volume within the factor-price equalization set is maximized when relative endowment differences are maximized.

Within the factor-price equalization set the world endowment of $\mathrm{E}$ and $\mathrm{L}$ are fixed at $\mathrm{OE}$ and OL respectively. Utilizing such a framework the effect of differential environmental standards takes on a very particular interpretation. Beginning with the endowment at $\mathrm{C}$, a move from $\mathrm{C}$ involves a switching of either or both factors between countries. For example, a move from $\mathrm{C}$ to $\mathrm{H}$ implies that Foreign gives $\mathrm{CH}$ of its environmental endowment to Home.

While such an exercise is useful to see how environmental policy can influence comparative advantage, it is not a realistic interpretation of operating standards. A more realistic interpretation of an increase in environmental standards is the decreasing of a country's effective environmental endowment while holding the other country's endowment fixed. Using this interpretation necessarily involves moving from one factor-price equalization set to another. However, the analysis is surprisingly simple.

Consider the original endowment point at $\mathrm{C}$. This point is on the VT $=0$ isotrade line. If the foreign country adopts environmental standards that decrease its endowment, the world endowment of environment is decreased from $O E$ to $O E^{\prime}$. The new origin for Foreign is $O^{* \prime}$. The new diagonal is shown as $O O^{* \prime}$. Now $\mathrm{C}$ is above the new $O O^{* \prime} \mathrm{VT}=0$ isotrade line. Thus, the change in standards for Foreign away from those of Home increases trade volume. Given linear isotrade lines this is a

general result and can be expressed as Proposition 2.

\section{Proposition 2}

Within the factor proportions model, a change in environmental regulation that increases relative endowment differences between countries increases trade volume.

b) Monopolistic Competition

Proposition 2 generates an empirically testable link between relative regulatory environmental differences and trade volume. However, it is inconsistent with an empirical model that includes country size as an independent determinant of trade volume. Therefore, we move to a monopolistically competitive setting that links relative standards and trade volume within a gravity framework.

Allow $\mathrm{M}$ to be monopolistically competitive where each variety $\mathrm{m}$ is equally priced, equally produced and earns zero profit. OA is now interpreted as many varieties of M. If $\mathrm{n}$ is the number of firms in industry $M, m$ $=M / n$.

Returning to Figure 1, allow the initial endowment to be at G. Given that $\mathrm{m}=\mathrm{m}^{*}$, Home is a net exporter of manufacturing goods. The value of Home exports is For- eign's share of world GDP $\left(\mathrm{s}^{*}\right)$ times the value of Home production of $M, s^{*} p_{M} n m$. Let the Home production of varieties be given by $M_{H}=m n$. Given that trade must be balanced in the absence of international borrowing overall trade volume is:

$$
V T=2 s * p_{M} n m=2 s * p_{M} M_{H}
$$

Assume each country is of equal size in terms of world GDP. The situation is depicted in Figure 2 where $O C=$ $O * C$ and the endowment point is $\mathrm{G}$.

Using the standard ^ notation to refer to relative change $\left(e . g ., \hat{s}=\frac{d s}{s}\right) \log$ differentiation of 3 generates:

$$
\stackrel{\wedge}{V T}=\hat{s}^{*}+\hat{M}_{H}
$$

Given that GDP + GDP* $=$ world GDP which is constant:

$$
\hat{S}^{*}=G \hat{D} P^{*}=\frac{-s}{s^{*}} G \hat{D} P
$$

Along $O Z, G \hat{D} P=\hat{M}_{H}$ so $\hat{V T}=\frac{-s}{s} G \hat{D P}+\hat{G D P}$, or

$$
\hat{V T}=\left(1-\frac{s}{s^{*}}\right) \hat{G D P}
$$

Using Equation (6), at $G, \frac{s}{s^{*}}=1$ implying that $\hat{V T}=0$. Moving from $\mathrm{O}$ to $\mathrm{G}$ along $O Z, s^{*}>s$ implying that $\hat{V T}>0$. Moving from $\mathrm{G}$ to $Z, s>s^{*}$, thus $\hat{V T}<0$. Trade volume increases from $\mathrm{O}$ to $\mathrm{G}$ and decreases from $G$ to $Z$ leading to Proposition 3 .

\section{Proposition 3}

Trade volume is maximized when countries are of equal size (gravity equation).

Now, allow the endowment point to move from $\mathrm{C}$ along $B B^{\prime}$ to $G^{\prime}$ so that holding relative size constant, Home is getting more $\mathrm{E}$ abundant. Along $B B^{\prime} \hat{s}^{*}=0$, thus:

$$
\hat{V T}=\hat{M}_{H}
$$

From $C$ to $G^{\prime}, \hat{M}_{H}>O$, trade volume is increasing resulting in Proposition 4.

\section{Proposition 4}

Within a factor-price equalization set, given country size is constant, trade volume increases as endowments become less similar.

Taking Propositions 3 and 4 together trade volume is maximized at $G^{\prime}$. Holding country size constant, as environmental regulations effectively makes the relative 


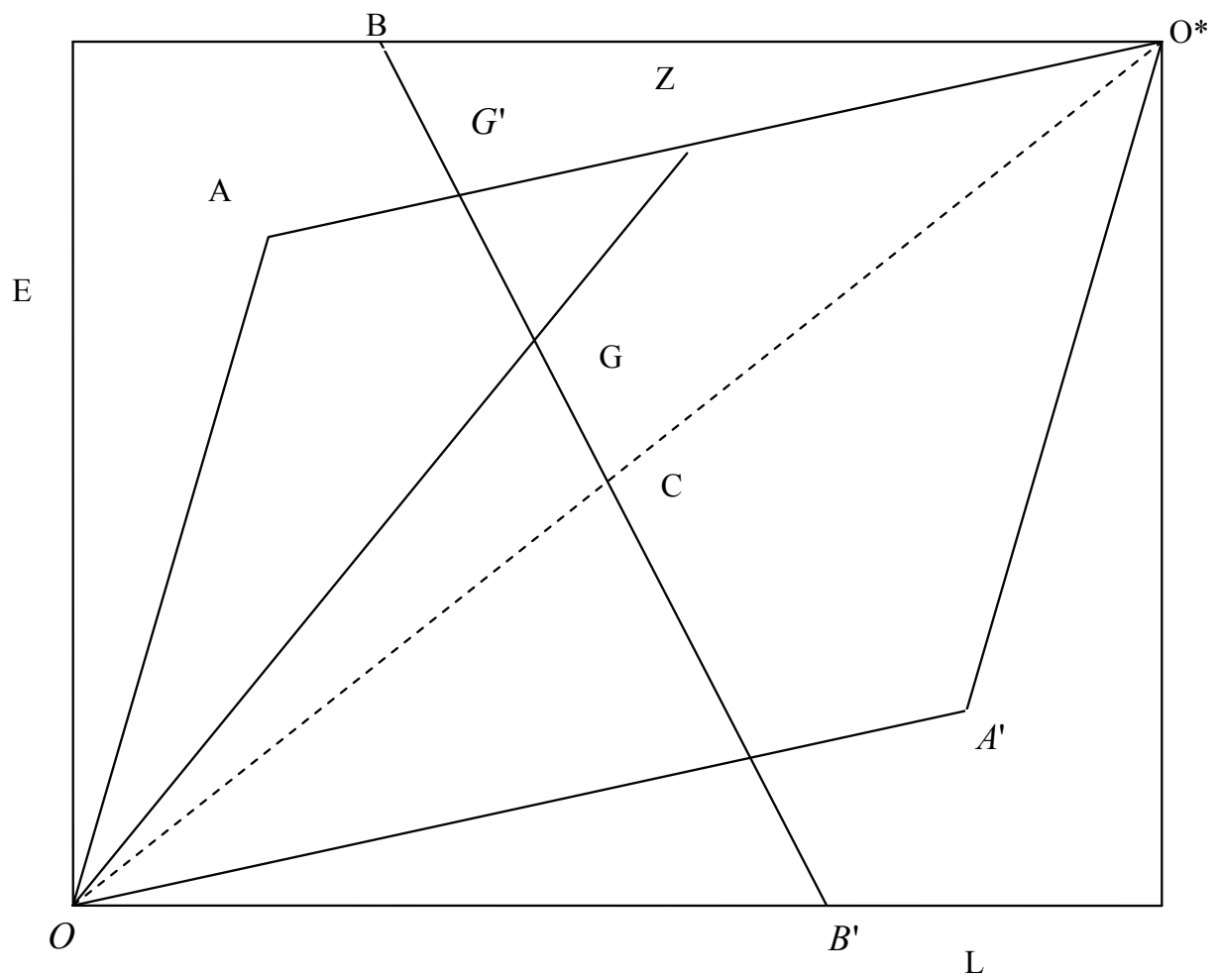

Figure 2. Factor-price equalization set when countries are of equal size.

endowments less similar between countries, bilateral trade volume increases. However, interpreting an increase in regulation as decreasing the effective size of the environmental endowment has a negative effect on GDP. Given the non linearity of isotrade lines within the monopolistic competitive framework [21], no general proposition can be stated beyond Proportion 4 .

Our empirical framework is developed using Proposition 4. In that framework we regress bilateral trade volume against, size, distance and environmental standards. The coefficient on environmental standards is interpreted holding relative size constant, thus moving along $B B^{\prime}$ toward $G^{\prime}$ is a change in relative environmental standards. From Propositions 2 and 4, the models based on the factor proportions model of interindustry trade predict that increases in the differences in stringency of environmental standards between countries increases bilateral trade volume.

\section{The Environmental Index}

The environmental index utilized in this study comes from the Global Competitiveness Report 2001-2002 [23].

\footnotetext{
${ }^{5}$ For a list of all 71 countries see Etsy and Porter [23].

${ }^{6}$ Data sources include the Global Competitiveness Report (GCR), Environmental Sensitivity Index (ESI), World Bank, and the World Economic Forum $[23,26]$.
}

The Environmental Regulatory Regime Index (ERRI) captures the effects of several variables in constructing one absolute ranking for 71 countries to measure environmental stringency ${ }^{5}$. This number of countries far exceeds other indices such as Walter and Ugelow [24] and Dasgupta and colleaugues [25] which include 23 and 31 countries respectively. The absolute ranking in the ERRI for each country ranges from -1.743 for Paraguay to 2.303 for Finland. The statistical methodology follows bilateral regressions and collects all significant variables to construct the ERRI.

For the purposes of the present paper, the variables that directly influence the ERRI are presented in detail below. For an explanation of the dependent variables and other indirect explanatory variables within the index see the Appendix. The ERRI is divided into two groups of independent variables. The first group is comprised of six categories: 1) stringency and environmental pollution standards, 2) sophistication of regulatory structure, 3) quality of the environmental information available, 4) extent of subsidization of natural resources, 5) strictness of government, and 6) quality of environmental institutions [23].

The six indicators of environmental stringency listed above give a very inclusive measure for regulation. Insight into a country's regulatory regime can be collected from these indicators because a variety of data collection processes are utilized in their construction. ${ }^{6}$ The data 
sources are mentioned below with a detailed description of the stringency indicator. The variables mentioned below represent the best available and comprise one of the most extensive, inclusive and accurate measurements of a country's environmental stringency.

The stringency and pollution standards category uses the Global Competitiveness Report (GCR) survey to measure air, water, toxic waste, and chemical regulation for a country. It is expected that this regulatory measure has an inverse relationship with all three dependent variables defined in the Appendix. Higher regulation results in lower urban particulates, lower $\mathrm{SO}_{2}$ concentrations and greater energy efficiency.

The sophistication of regulatory structure category measures the characteristics of the regime. This concerns the clarity in which the regulations are defined, the progressive nature of the regime, the structure of the regime to promote competitiveness, and the relationship between business and government. This category is also expected to have an inverse relationship with the environmental performance (dependent) variables.

The category regarding the quality of environmental information available rests on data from the World Economic Forum and the Environmental Sustainability Index (ESI). This measures the extent to which environmental and economic data are available for policy making and regulatory enforcement. This study relies on four proxy variables for this measure: 1) the extent to which data is collected, 2) the extent to which sustainable development data is available coupled with plans supporting environmental policy, 3) structure assessing environmental decisions, and 4) the extent to which a country has plans for environmental action. Again, there should be a negative relationship between this category and the dependent variables.

The extent of the subsidization of natural resources category recovers data from the GCR survey. This captures the extent to which a country subsidizes energy and natural resources. However, there is expected to be a positive relationship between the natural resource subsidies and the three environmental performance variables.

The strictness of enforcement category measures two factors within a country. The enforcement of environmental regulations are measured coupled with the extent to which a country follows through with international agreements regarding environmental policy. There should be an inverse relationship between this measure and the dependent variables as countries that have high environ-

\footnotetext{
${ }^{7}$ For distance and border data see www.macalester.edu/research/economics/page/Haveman/Trade.Resources/Data/Gravity/dist.txt.

${ }^{8}$ The countries are Argentina, Australia, Austria, Bulgaria, Bolivia, Canada, Chile, China, Colombia, Costa Rica, Denmark, Ecuador, Egypt, Spain, Finland, France, United Kingdom, Greece, Hungary, Indonesia, India, Ireland, Italy, Jordan, Japan, Korea, Mexico, Malaysia Netherlands, Norway, New Zealand, Peru, Philippines, Poland, Portugal, Sweden, Thailand, United States and Venezuela.
}

mental enforcement should expect to have lower level of pollution concentration and higher energy efficiency.

The final category involves the quality of environmental institutions of a country. This measure captures the effect that nongovernmental organizations (NGOs) have on enforcing the environmental decisions and actions of the government. This may include environmental organizations that further research to aid government endeavors or even institutions that become substitutes for the governmental sector. These NGOs may increase a country's ability to control for pollution by increasing awareness and information on environmental issues. Data is gathered from the ESI and this measure is expected to have a negative relationship with the dependant variables.

\section{Empirical Analysis and Data}

The data on bilateral trade volume was recovered from the World Bank for 1999. The aggregate of bilateral trade volume from country $i$ to country $j$ was collected by summing the total exports from $i$ to $j$ with the imports from $j$ to $i$. Since, duplicate pairings within the data set would cause statistical problems the country that is alphabetically first was considered $i$ and no duplicate pairings were included. Table 1 expresses the pairings of bilateral trade volume and ERRI Index value for each country.

The data for the remaining variables was collected as follows. The real 1999 GDP data is in billions of 2000 U.S. dollars while the per capita 1999 data was in 2000 U.S. dollars and found at the World Bank development indicators. The distance measure is in kilometers. ${ }^{7}$ This model is measured across 39 countries for the year 1999. ${ }^{8}$

The gravity model augmented to include differences in environmental regulation is given in Equation (8). Equations (9) to (11) represent logical extensions of the model that are explained in more detail below. Each country's ERRI number is represented as $\mathfrak{R}$. The well-known effect of sharing a border is represented with a dummy variable $\delta_{i j}$ with a value of 1 representing countries $i$ and $j$ sharing a border.

$$
\begin{aligned}
\ln X_{i j}= & \theta_{0}+\theta_{1} \ln G D P_{i}+\theta_{2} \ln G D P_{j} \\
& +\theta_{3} \delta_{i j}+\theta_{4} \ln D I S T_{i j} \\
& +\theta_{5} \ln \left|\Re_{i}-\Re_{j}\right|+\vartheta_{i j} \\
\ln X_{i j}= & \theta_{0}+\theta_{1} \ln G D P_{i}+\theta_{2} \ln G D P_{j} \\
& +\theta_{3} \delta_{i j}+\theta_{4} \ln D I S T_{i j}+\theta_{5}\left|\Re_{i}-\Re_{j}\right| \\
& +\theta_{6}\left|\Re_{i}-\mathfrak{R}_{j}\right|^{2}+\vartheta_{i j}
\end{aligned}
$$


Table 1. Pairings of bilateral trade volume and ERRI index across countries.

\begin{tabular}{|c|c|c|}
\hline Country & $\begin{array}{l}\text { Bilateral Trade Volume } \\
\text { (1999: Billions of US\$)* }\end{array}$ & ERRI (1999) \\
\hline Argentina & 23.98 & -0.732 \\
\hline Australia & 69.11 & 1.083 \\
\hline Austria & 49.67 & 1.641 \\
\hline Bulgaria & 3.30 & -0.584 \\
\hline Bolivia & 2.22 & -0.743 \\
\hline Canada & 370.96 & 1.297 \\
\hline Chile & 17.77 & 0.177 \\
\hline China & 220.04 & -0.348 \\
\hline Colombia & 11.88 & -0.416 \\
\hline Costa Rica & 7.63 & -0.078 \\
\hline Denmark & 52.82 & 1.384 \\
\hline Ecuador & 3.29 & -1.616 \\
\hline Egypt & 1.51 & -0.224 \\
\hline Finland & 45.11 & 2.303 \\
\hline France & 312.75 & 1.464 \\
\hline Greece & 21.68 & -0.619 \\
\hline Hungary & 12.45 & 0.283 \\
\hline Indonesia & 46.19 & -0.758 \\
\hline India & 34.47 & -0.759 \\
\hline Ireland & 82.67 & 0.546 \\
\hline Italy & 228.14 & 0.498 \\
\hline Jordan & 2.23 & 0.002 \\
\hline Japan & 473.60 & 1.057 \\
\hline Korea & 168.83 & -0.121 \\
\hline Mexico & 240.43 & -0.602 \\
\hline Malaysia & 85.43 & -0.127 \\
\hline Netherlands & 177.71 & 1.747 \\
\hline Norway & 34.67 & 1.045 \\
\hline New Zealand & 18.47 & 1.299 \\
\hline Peru & 6.74 & -0.722 \\
\hline Philippines & 31.96 & -1.014 \\
\hline Poland & 24.08 & 0.005 \\
\hline Portugal & 38.48 & -0.028 \\
\hline Spain & 158.27 & 0.437 \\
\hline Sweden & 75.25 & 1.772 \\
\hline Thailand & 54.68 & -0.389 \\
\hline UK & 345.73 & 1.185 \\
\hline United States & 815.80 & 1.184 \\
\hline Venezuela & 17.79 & -1.079 \\
\hline
\end{tabular}

*Bilateral trade volume based on sample of 39 countries

$$
\begin{aligned}
\ln X_{i j}= & \theta_{0}+\theta_{1} \ln G D P_{i}+\theta_{2} \ln G D P_{j} \\
& +\theta_{3} \delta_{i j}+\theta_{4} \ln D I S T_{i j}+\theta_{5} \ln \left|\mathfrak{R}_{i}-\mathfrak{R}_{j}\right| \\
& +\theta_{7} \min \left(\mathfrak{R}_{i}, \Re_{j}\right)+\theta_{8} \max \left(\mathfrak{R}_{i}, \Re_{j}\right)+\vartheta_{i j}
\end{aligned}
$$

\footnotetext{
${ }^{9}$ The original ERRI values ran from -1.743 to 2.303 . In order to take the natural $\log$ of the max and min we added 2 to each value insuring that all values are positive.

${ }^{10} \mathrm{We}$ also ran regressions without taking the natural $\log$ of $\mathrm{R} \max$ and $\mathrm{R} \mathrm{min}$. The results were consistent though less significant.
}

$$
\begin{aligned}
\ln X_{i j}= & \theta_{0}+\theta_{1} \ln G D P_{i}+\theta_{2} \ln G D P_{j} \\
& +\theta_{3} \delta_{i j}+\theta_{4} \ln D I S T_{i j}+\theta_{5}\left|\mathfrak{R}_{i}-\mathfrak{R}_{j}\right| \\
& +\theta_{6}\left|\mathfrak{R}_{i}-\mathfrak{R}_{j}\right|^{2}+\theta_{7} \min \left(\mathfrak{R}_{i}, \mathfrak{R}_{j}\right) \\
& +\theta_{8} \max \left(\mathfrak{R}_{i}, \mathfrak{R}_{j}\right)+\vartheta_{i j}
\end{aligned}
$$

The results from Equations (8) through (11) are presented in Table 2. Equation (8) represents the log linearized gravity model with a regulatory distance variable, $\left|\mathfrak{R}_{i}-\mathfrak{R}_{j}\right|$, included as the absolute value of environmental differences. The absolute value is used to express the effective differences without regard to sign. Gravity theory suggests that the larger the masses the greater the force. The significance of both $G D P_{i}$ and $G D P_{j}$ is no surprise as larger countries trade more with each other. As we further expect, there is a significant positive border effect captured by $\delta_{i j}$ and a significant negative distance effect captured by $D I S T_{i j}$. These four measures appear strongly significant across the four equations above. The regulatory distance, $\left|\mathfrak{R}_{i}-\mathfrak{R}_{j}\right|$, displays a positive but weak effect on bilateral trade volume.

Equation (9) includes a quadratic regulatory distance term, $\left|\mathfrak{R}_{i}-\mathfrak{R}_{j}\right|^{2}$, measuring any diminishing affect of differences in standards. We would expect that this measurement be negative. The natural logarithm is dropped in this regression to avoid perfect multicollinearity among the exogenous variables. The absolute distance is still weakly positive but the point estimate is indicating a much stronger effect. The quadratic measure expresses a very weak negative relationship.

Equations (10) and (11) add the log of the minimum and maximum regulations per country. ${ }^{9}$ The results from Equations (8) and (9) can be interpreted as giving weak support to the pollution havens hypothesis and the race-to-the-bottom for low standard countries since a decrease in standards for the low standard country increases trade volume. To better control for this effect, we add the high and low value of standards. A negative value on $\theta_{7}$, which is the coefficient for the low standard country, would indicate that a decrease in standards of the low standard country increases trade volume. Both regressions produce positive and generally significant effects of increased standards on trade volume for each country. When the regulatory distance measure is dropped, Equation (11) shows a positive and significant relationship between an increase in the standards of the higher regulated country and trade volume. Both equations yield results refuting the race-to-the-bottom hypothesis. No country has an incentive to lower environmental standards in order to increase bilateral trade volume given that the coefficient for the low standards country is positive and significant at the $10 \%$ level in both equations. ${ }^{10}$ 
Table 2. Results from OLS regression of the natural log of bilateral trade volume between country $i$ and $j$ on explanatory variables in column one.

\begin{tabular}{|c|c|c|c|c|}
\hline & $(8)$ & $(9)$ & $(10)$ & $(11)$ \\
\hline & $\ln X_{i j}$ & $\ln X_{i j}$ & $\ln X_{i j}$ & $\ln X_{i j}$ \\
\hline $\ln G D P_{i}$ & $\begin{array}{c}1.061 * * * \\
(35.75)\end{array}$ & $\begin{array}{c}1.059 * * * \\
(35.57)\end{array}$ & $\begin{array}{c}1.025^{* * *} \\
(32.52)\end{array}$ & $\begin{array}{c}1.024 * * * \\
(32.46)\end{array}$ \\
\hline $\ln G D P_{j}$ & $\begin{array}{c}0.941 * * * \\
(31.41)\end{array}$ & $\begin{array}{c}0.939^{* * *} \\
(31.29)\end{array}$ & $\begin{array}{l}0.909 * * * \\
(28.99)\end{array}$ & $\begin{array}{l}0.911 * * * \\
(28.90)\end{array}$ \\
\hline$\delta_{i j}$ & $\begin{array}{c}1.268^{* * *} \\
(4.20)\end{array}$ & $\begin{array}{c}1.268 * * * \\
(4.20)\end{array}$ & $\begin{array}{c}1.344 * * * \\
(4.47)\end{array}$ & $\begin{array}{c}1.346^{* * *} \\
(4.48)\end{array}$ \\
\hline $\ln D I S T_{i j}$ & $\begin{array}{c}-0.897 * * * \\
(-16.35)\end{array}$ & $\begin{array}{c}-0.897 * * * \\
(-16.29)\end{array}$ & $\begin{array}{c}-0.848^{* * *} \\
(-14.98)\end{array}$ & $\begin{array}{c}-0.852^{* * *} \\
(-14.98)\end{array}$ \\
\hline$\left|\mathfrak{R}_{i}-\mathfrak{R}_{j}\right|$ & & $\begin{array}{l}0.217 \\
(1.15)\end{array}$ & & $\begin{array}{l}0.287 \\
(1.11)\end{array}$ \\
\hline $\ln \left|\Re_{i}-\mathfrak{R}_{j}\right|$ & $\begin{array}{l}0.038 \\
(0.96)\end{array}$ & & $\begin{array}{l}0.034 \\
(0.53)\end{array}$ & \\
\hline$\left|\mathfrak{R}_{i}-\Re_{j}\right|^{2}$ & & $\begin{array}{l}-0.059 \\
(-0.88)\end{array}$ & & $\begin{array}{l}-0.041 \\
(-0.062)\end{array}$ \\
\hline $\ln \min \left(\mathfrak{R}_{i}, \mathfrak{R}_{j}\right)$ & & & $\begin{array}{l}0.269^{*} \\
(1.68)\end{array}$ & $\begin{array}{l}0.446 \\
(1.57)\end{array}$ \\
\hline $\ln \max \left(\mathfrak{R}_{i}, \Re_{j}\right)$ & & & $\begin{array}{l}0.235 \\
(0.94)\end{array}$ & $\begin{array}{l}-0.076 \\
(-0.16)\end{array}$ \\
\hline $\begin{array}{l}* * * * * * \text { denotes significance levels of } 90 \%, 95 \% \text {, } \\
\text { and } 99 \% \text { respectively. Test statistics are in parentheses }\end{array}$ & $\begin{array}{l}\mathrm{R}^{2}=0.785 \\
\text { \# of obs. }=741\end{array}$ & $\begin{array}{c}\mathrm{R}^{2}=0.785 \\
\text { \# of obs. }=741\end{array}$ & $\begin{array}{c}\mathrm{R}^{2}=0.788 \\
\text { \# of obs. }=741\end{array}$ & $\begin{array}{c}\mathrm{R}^{2}=0.788 \\
\text { \# of obs. }=741\end{array}$ \\
\hline
\end{tabular}

Where: In denotes the natural logarithm; $X_{i j}$ denotes gross bilateral trade flows between country $i$ and $j ; G D P_{i}, G D P_{j}$ denote the GDP of country $i$ and $j$ respectively; $D I S T_{i j}$ denotes the distance between country $i$ and $j ; \Re_{i}, \Re_{j}$ denote the environmental regulation index of country $i$ and $j$ respectively; $\delta_{i j}$ denotes a dummy variable equal to 1 if country $i$ and $j$ share a border, 0 otherwise; $\vartheta_{i j}$ denote the error terms.

To control for country size, per capita GDP is substituted into Equations (8), (9), (10), and (11) to generate Equations (12) through (15). A useful economic interpretation of the gravity model is that size is a measure of the purchasing power of each country. Therefore an alternative measure of size is income per capita. Countries closer in terms of per capita income will be expected to trade more.

$$
\begin{aligned}
\ln X_{i j}= & \theta_{0}+\theta_{1} \ln \left(\frac{G D P_{i}}{N_{i}}\right)+\theta_{2} \ln \left(\frac{G D P_{j}}{N_{j}}\right) \\
& +\theta_{3} \delta_{i j}+\theta_{4} \ln D I S T_{i j}+\theta_{5} \ln \left|\Re_{i}-\Re_{j}\right| \vartheta_{i j} \\
\ln X_{i j}= & \theta_{0}+\theta_{1} \ln \left(\frac{G D P_{i}}{N_{i}}\right)+\theta_{2} \ln \left(\frac{G D P_{j}}{N_{j}}\right) \\
& +\theta_{3} \delta_{i j}+\theta_{4} \ln D I S T_{i j}+\theta_{5}\left|\Re_{i}-\Re_{j}\right| \\
& +\theta_{6}\left|\Re_{i}-\Re_{j}\right|^{2}+\vartheta_{i j} \\
\ln X_{i j}= & \theta_{0}+\theta_{1} \ln \left(\frac{G D P_{i}}{N_{i}}\right)+\theta_{2} \ln \left(\frac{G D P_{j}}{N_{j}}\right) \\
& +\theta_{3} \delta_{i j}+\theta_{4} \ln D I S T_{i j}+\theta_{5} \ln \left|\Re_{i}-\Re_{j}\right| \\
& +\theta_{7} \min \left(\Re_{i}, \Re_{j}\right)+\theta_{8} \max \left(\Re_{i}, \Re_{j}\right)+\vartheta_{i j}
\end{aligned}
$$

$$
\begin{aligned}
\ln X_{i j}= & \theta_{0}+\theta_{1} \ln \left(\frac{G D P_{i}}{N_{i}}\right)+\theta_{2} \ln \left(\frac{G D P_{j}}{N_{j}}\right) \\
& +\theta_{3} \delta_{i j}+\theta_{4} \ln D I S T_{i j}+\theta_{5}\left|\Re_{i}-\Re_{j}\right| \\
& +\theta_{6}\left|\Re_{i}-\Re_{j}\right|^{2}+\theta_{7} \min \left(\mathfrak{R}_{i}, \Re_{j}\right) \\
& +\theta_{8} \max \left(\Re_{i}, \Re_{j}\right)+\vartheta_{i j}
\end{aligned}
$$

The results from Equations 12 through 15 are presented in Table 3. Surprisingly, Equation (12) shows a negative but insignificant relationship between regulatory differences and trade volume. In controlling for diminishing returns by including the quadratic term, Equation (13) shows a positive marginally significant effect. As found in the previous results, Equations (14) and (15) present strong evidence against the race-to-the-bottom hypothesis. Holding income per capita, distance, borders, and regulatory differences constant, increased standards of the low standard country increases trade volume. The point estimates indicate that a $1 \%$ increase in the standards of the low standard country results in an increase of trade volume of $0.8 \%$ and $0.9 \%$. Using the ERRI these results indicate that, for example, countries with index values of 2 and 1.5 trade more with each other than countries with index values with 1 and 0.5 even after controlling for the effect of income per capita. 
Table 3. Results from OLS regression of the natural log of bilateral trade volume between country $i$ and $j$ on explanatory variables in column one.

\begin{tabular}{|c|c|c|c|c|}
\hline & (12) & (13) & (14) & (15) \\
\hline & $\ln X_{i j}$ & $\ln X_{i j}$ & $\ln X_{i j}$ & $\ln X_{i j}$ \\
\hline $\ln \left(\frac{G D P_{i}}{N_{i}}\right)$ & $\begin{array}{c}0.742 * * * \\
(11.58)\end{array}$ & $\begin{array}{c}0.737 * * * \\
(11.49)\end{array}$ & $\begin{array}{c}0.572 * * * \\
(6.59)\end{array}$ & $\begin{array}{c}0.601 * * * \\
(6.64)\end{array}$ \\
\hline $\ln \left(\frac{G D P_{j}}{N_{j}}\right)$ & $\begin{array}{c}0.65^{* * *} \\
(9.88)\end{array}$ & $\begin{array}{c}0.641 * * * \\
(9.74)\end{array}$ & $\begin{array}{c}0.483 * * * \\
(5.52)\end{array}$ & $\begin{array}{c}0.516 * * * \\
(5.55)\end{array}$ \\
\hline$\delta_{i j}$ & $\begin{array}{c}1.139 * * \\
(2.14)\end{array}$ & $\begin{array}{c}1.151^{* *} \\
(2.17)\end{array}$ & $\begin{array}{c}1.284^{* *} \\
(2.43)\end{array}$ & $\begin{array}{l}1.29 * * \\
(2.45)\end{array}$ \\
\hline $\ln D I S T_{i j}$ & $\begin{array}{c}-0.677 * * * \\
(-6.81)\end{array}$ & $\begin{array}{c}-0.663 * * * \\
(-6.65)\end{array}$ & $\begin{array}{c}-0.626 * * * \\
(-6.28)\end{array}$ & $\begin{array}{c}-0.629 * * * \\
(-6.33)\end{array}$ \\
\hline$\left|\mathfrak{R}_{i}-\mathfrak{R}_{j}\right|$ & & $\begin{array}{l}0.461 \\
(1.38)\end{array}$ & & $\begin{array}{c}0.947 * * \\
(2.01)\end{array}$ \\
\hline $\ln \left|\Re_{i}-\Re_{j}\right|$ & $\begin{array}{l}-0.071 \\
(-1.00)\end{array}$ & & $\begin{array}{l}0.057 \\
(0.49)\end{array}$ & \\
\hline$\left|\Re_{i}-\Re_{j}\right|^{2}$ & & $\begin{array}{c}-0.217^{*} \\
(-1.84)\end{array}$ & & $\begin{array}{l}-0.185 \\
(-1.59)\end{array}$ \\
\hline $\ln \min \left(\Re_{i}, \Re_{j}\right)$ & & & $\begin{array}{c}0.931 * * * \\
(3.25)\end{array}$ & $\begin{array}{l}1.38 * * * \\
(2.74)\end{array}$ \\
\hline $\ln \max \left(\mathfrak{R}_{i}, \mathfrak{R}_{j}\right)$ & & & $\begin{array}{l}0.109 \\
(0.21)\end{array}$ & $\begin{array}{l}-0.874 \\
(-0.88)\end{array}$ \\
\hline $\begin{array}{l}* * * * * * \text { denotes significance levels of } 90 \%, 95 \% \text {, } \\
\text { and } 99 \% \text { respectively. Test statistics are in parentheses }\end{array}$ & $\begin{array}{c}\mathrm{R}^{2}=0.332 \\
\text { \# of obs. }=741\end{array}$ & $\begin{array}{c}\mathrm{R}^{2}=0.335 \\
\text { \# of obs. }=741\end{array}$ & $\begin{array}{c}\mathrm{R}^{2}=0.338 \\
\text { \# of obs. }=741\end{array}$ & $\begin{array}{c}\mathrm{R}^{2}=0.347 \\
\text { \# of obs. }=741\end{array}$ \\
\hline
\end{tabular}

\section{Conclusions}

This paper makes four contributions. First, we develop a theoretical model of the relationship between environmental standards and bilateral trade volume within a factor proportions framework. We further extend this model to consider monopolistic competition that generates a gravity equation. This allows us to produce an empirical equation of the relationship between standards and trade volume with strong theoretical foundations.

Second, we utilize a new more comprehensive index of environmental stringency in our empirical analysis of the stringency-trade volume relationship than has been utilized in previous studies. This index represents a comprehensive measure of overall environmental stringency by country and allows for a relatively large sample of countries. We conduct our empirical analysis over 39 developed and less developed countries.

Third, we fully utilize the concept of comparative advantage in a gravity equation framework to address the question of the relationship between environmental standards and bilateral trade volume. We find that differentces in environmental standards have a weak but positive effect on trade volume. At the very least, our results indicate that differential standards between countries do not hinder trade volume. A country that is considering a unilateral move to increase standards will not appear to pay in terms of decreased trade volume.

Finally, we develop a test of whether low standard countries have an incentive to decrease standards in order to increase trade volume. Controlling for environmental differences, and measures of country size (GDP and GDP per capita) we find that trade volume increases as the standards of the low standard country increase. Countries higher on the ERRI trade more with each other than similarly differenced countries lower on the index. This evidence refutes the race-to-the-bottom and pollution havens hypotheses of trade, because neither high nor lower standard countries increase trade volume by reducing standards. All of our evidence runs in the opposite direction.

\section{References}

[1] R. Pethig, "Pollution, Welfare and Environmental Policy in the Theory of Comparative Advantage," Journal of Environmental Economics and Management, Vol. 2, No. 3, 1976, pp. 160-169.

[2] H. Siebert, "Environmental Quality and Gains from Trade," Kyklos, Vol. 30, No. 4, 1977, pp. 657-673.

[3] R. Ratnayake, "Do Stringent Environmental Regulations Reduce International Competitiveness? Evidence from an 
Inter-Industry Analysis," International Journal of the Economics of Business, Vol. 5, No. 1, 1998, pp. 77-96.

[4] R. Stewart, "Environmental Regulation and International Competitiveness," Yale Law Journal, Vol. 102, No. 8, 1993, pp. 2039-2106.

[5] J. M. Grether and J. D. Melo, "Globalization and Dirty Industries: Do Pollution Havens Matter?" Center for Economic Policy Research, No. 3932, 2003.

[6] A. Levinson and S. Taylor, (2004). "Unmasking the Pollution Haven Effect," NBER Working Paper Series, No. 10629, 2004, pp. 1-32.

[7] J. A. Frankel and A. K. Rose, "Is Trade Good or Bad for the Environment? Sorting Out the Causality," Review of Economics and Statistics, Vol. 87, No. 1, February 2005, pp. 85-91.

[8] A. Levinson, "Environmental Regulations and Manufactures' Location Choice: Evidence from the Census of Manufactures," Journal of Public Economics, Vol. 62, No. 1, 1996, pp. 5-29.

[9] J. Tobey, "The Effects of Domestic Environmental Policies and Patterns of World Trade: An Empirical Test," Kyklos, Vol. 43, No. 2, 1990, pp. 191-209.

[10] M. E. Porter, "America's Green Strategy," Scientific American, Vol. 264, No. 4, April 1991, p. 168.

[11] M. Porter and C.V.D. Linde, "Towards a New Conception of the Environment-Competitiveness Relationship," Journal of Economic Perspectives, Vol. 9, No. 4, 1995, pp. 97-118.

[12] S. Alpay, "What Do We Know About the Interactions between Trade and the Environment? A Survey of the Literature," Bilkent University Working Paper, No. 991, 1999.

[13] C. van Beers and J.C.J.M. van den Bergh, "An Overview of Methodological Approaches in the Analysis of trade and the Environment", Journal of World Trade, Vol. 30, No. 1, 1996, pp. 143-167.

[14] J. Wilson, T. Otsuki and M. Sewadeh, "Dirty Exports and Environmental Regulation: Do Standards matter to Trade?" Developmental Research Group, the World Bank, 2002.
[15] D. Trefler, "The Case of the Missing Trade and Other Mysteries," The American Economic Review, Vol. 85, No. 5, 1995, pp. 1029-1046.

[16] J. Tinbergen, "Shaping the World Economy: Suggestions for an International Economic Policy," Twentieth Century Fund, New York, 1962.

[17] K. Head, "Gravity for Beginners," 2003. http://economics.ca./keith/gravity.pdf

[18] J. Jug and D. Mirza, "Environmental Regulations in Gravity Equations: Evidence from Europe," The World Economy, Vol. 28, No. 11, 2005, pp. 1591-1615.

[19] C. van Beers and J. C. J. M. van den Bergh, "An Empirical Multi-Country Analysis of the Impact of Environmental Regulations on Foreign Trade Flows," Kyklos, Vol. 50, No. 1, 1997, pp. 29-46.

[20] M. N. Harris, L. Konya and L. Matyas, "Modeling the Impact of Environmental Regulations on Bilateral Trade Flows: OECD, 1990-1996," The World Economy, Vol. 25, No. 3, 2002, pp. 387-405.

[21] E. Helpman and P. Krugman, "Market Structure and Foreign Trade: Increasing Returns, Imperfect Competition, and the International Economy," MIT Press, Cambridge, 1985.

[22] E. Helpman, "Imperfect Competition and International Trade: Evidence from Fourteen Industrial Countries," Journal of the Japanese and International Economies, Vol. 1, No. 1, 1987, pp. 62-81.

[23] D. Esty and M. Porter, "Ranking National Environmental Regulation and Performance: A Leading Indicator or Future Competitiveness?" The Global Competitiveness Report 2001-2002, Oxford University Press, New York, 2001.

[24] I. Walter and J. Ugelow, "Environmental policies in developing Countries," Ambio, Vol. 8, No. 23, pp. 102-109.

[25] S. Dasgupta, A. Mody, S. Roy and D.Wheeler, "Environmental Regulation and Development: A Cross Country Empirical Analysis," Oxford Development Studies, Vol. 29, 2001, pp. 173-187.

[26] World Bank, “Trade Database and Developmental Indicators,"1999. URL:http://web.worldbank.org. 


\section{Appendix}

There are three dependent variables used in the ERRI. They are 1) the level of urban particulate matter, 2) average $\mathrm{SO}_{2}$ concentration which is normalized by urban population, 3) energy efficiency. Particulate matter is collected from the World Bank and the World Health organization (WHO). This measures the concentration of air-born dust and is therefore a measure of air quality. A higher particulate concentration corresponds to a higher pollution level. Similarly, the $\mathrm{SO}_{2}$ concentration also measures the quality of air and serves as a gauge for levels of pollution. The energy efficiency measure utilizes U.S. Department of Energy data and captures the aggregate amount of energy consumption per unit of GDP for each country. The higher the level of energy efficiency the lower the amount of energy consumed per unit of GDP and therefore the more efficient a country's energy consumption.
The ERRI is divided into two groups of independent variables. The first group is comprised of six categories: 1) stringency and environmental pollution standards, 2) sophistication of regulatory structure, 3) quality of the environmental information available, 4) extent of subsidization of natural resources, 5) strictness of government, and 6) quality of environmental institutions [23]. The second group of independent variables is concerned with a country's economic and legal context. This group can be further divided into two categories: 1) administrative infrastructure which includes but is not limited to measures of civil/political rights, private property protection, corruption, and judiciary independence and 2) a country's technical capacity measuring scientific and technological advancement. A number of proxies are used in this category such as the number of scientists and engineers, intellectual property protection, strength of scientific community, government commitment to technological research and advancements, and the adoption of foreign technologies. 